\title{
Cannabinoid Regulation of Fear and Anxiety: an Update
}

\author{
Eleni P. Papagianni ${ }^{1} \cdot$ Carl W. Stevenson $^{1}$
}

Published online: 27 April 2019

(C) The Author(s) 2019

\begin{abstract}
Purpose of Review Anxiety- and trauma-related disorders are prevalent and debilitating mental illnesses associated with a significant socioeconomic burden. Current treatment approaches often have inadequate therapeutic responses, leading to symptom relapse. Here we review recent preclinical and clinical findings on the potential of cannabinoids as novel therapeutics for regulating fear and anxiety.

Recent Findings Evidence from preclinical studies has shown that the non-psychotropic phytocannabinoid cannabidiol and the endocannabinoid anandamide have acute anxiolytic effects and also regulate learned fear by dampening its expression, enhancing its extinction and disrupting its reconsolidation. The findings from the relevant clinical literature are still very preliminary but are nonetheless encouraging.

Summary Based on this preclinical evidence, larger-scale placebo-controlled clinical studies are warranted to investigate the effects of cannabidiol in particular as an adjunct to psychological therapy or medication to determine its potential utility for treating anxiety-related disorders in the future.
\end{abstract}

Keywords Cannabidiol $\cdot$ Consolidation $\cdot$ Endocannabinoid $\cdot$ Extinction $\cdot$ Fear conditioning $\cdot$ Reconsolidation

\section{Introduction}

Anxiety- and trauma-related disorders are the most common psychiatric diseases and are associated with inadequate treatment options and thus high social and economic costs. Psychological treatments are often limited or temporary in their effectiveness, while medications can lack efficacy or have unwanted side effects in a considerable number of patients. Psychological therapies can also be combined with medications to enhance treatment synergistically, but some medications can interfere with these therapies. Better options are therefore urgently needed for treating these disorders [1].

With the decriminalization of cannabis, availability of cannabis-derived chemicals (i.e. cannabinoids), and anecdotal evidence for the anxiolytic potential of cannabinoids all becoming ever more widespread, it is important to take stock of the empirical evidence to determine if cannabinoids can live

This article is part of the Topical Collection on Anxiety Disorders

Carl W. Stevenson

carl.stevenson@nottingham.ac.uk

1 School of Biosciences, University of Nottingham, Sutton Bonington Campus, Loughborough LE12 5RD, UK up to their hype as an option for treating anxiety-related disorders in the future. In this narrative review, we begin by describing these disorders and the current therapeutic approaches used in their treatment. We then review the preclinical and clinical studies that have investigated cannabinoid regulation of fear and anxiety. We conclude by outlining future directions for driving forward this promising avenue of research.

\section{Anxiety- and Trauma-Related Disorders and Their Treatment: Current Therapeutic Approaches}

Anxiety and fear are emotional responses that occur in anticipation of potential threat or when facing imminent danger, respectively. These responses are adaptive when they occur appropriately in response to relevant aversive stimuli, but they become maladaptive when expressed inappropriately under benign conditions and can lead to the development of anxiety- and trauma-related disorders [2]. The anxiety disorders include generalized anxiety, panic, social anxiety, phobias and separation anxiety, with post-traumatic stress-disorder (PTSD) and obsessive-compulsive disorder being related 
to but now classed separately from anxiety disorders. Collectively, these anxiety-related disorders are the most prevalent psychiatric diseases and are therefore a significant socioeconomic burden, given their high costs to the health care system and their association with long-term disability, lost work productivity and disrupted social relationships [3]. These disorders are associated with perturbed cognition and emotional regulation. For example, they share common psychological (e.g. excessive fear, apprehension, disturbed concentration and sleep) and somatic (e.g. tachycardia, heart palpitations, sweating) symptoms, with arousal and avoidance behaviour thought to predict long-term disability $[4 \cdot, 5]$. Symptom overlap among the different anxiety-related disorders and with other psychiatric diseases is a diagnostic challenge, while self-medication with alcohol and/or other drugs can progress to substance abuse and lead to significant comorbidity between these diseases $[4 \cdot, 6]$.

Anxiety-related disorders are treated using psychological therapies or/and medications. The various psychological approaches include cognitive behavioural therapy, exposure therapy, cognitive processing therapy and eye desensitization reprocessing, with the aim of reducing avoidance behaviour and distress [4י, 7]. Selective serotonin reuptake inhibitors (SSRIs) are typically the first choice of medication, but other types of anti-depressants can be used if the response to SSRI treatment is inadequate; selective noradrenaline reuptake inhibitors (SNRIs) are favoured over tricyclics and monoamine oxidase inhibitors due to their more favourable safety and tolerability profile. Other drug therapies include anti-seizure medications, serotonin1A (5-HT1A) receptor agonists (e.g. buspirone), short-term benzodiazepine treatment for acute anxiety and beta-blockers for reducing somatic symptoms $[8,9]$.

While psychological and pharmacological therapies are effective $[7,8]$, both treatment approaches have their drawbacks. The effects of certain psychological treatments (e.g. exposure therapy) can be short-lived, limited outside of the therapeutic context and hindered by drugs of abuse and even certain anxiolytics, all of which can result in symptom relapse after treatment [1]. Medications can lack or have incomplete therapeutic effects, which often take weeks to commence in the case of first-line SSRI or SNRI treatment. Moreover, these treatments can also cause adverse effects (e.g. anxiogenesis, insomnia, agitation, headache, appetite and gastrointestinal disturbances, sexual dysfunction) prior to the onset of or along with their therapeutic effects. Benzodiazepines can cause unwanted central nervous system depressant effects, tolerance and withdrawal with abrupt discontinuation and have abuse liability. This has limited their recent use to managing acute anxiety in the short-term until the onset of therapeutic effects with first-line SSRI/SNRI treatment [9]. Benzodiazepines may also enhance the risk of developing PTSD and comorbid substance abuse disorders, worsen PTSD symptoms and reduce the efficacy of psychological therapies for PTSD treatment [10]. Taken together, these issues highlight the limitations of psychological therapies and medications currently used for treating anxiety-related disorders.

\section{Cannabinoids: a Brief Overview}

Cannabis sativa is one of the oldest plants known for its recreational and purported medicinal properties. It consists of more than 400 chemicals known collectively as phytocannabinoids, over 100 of which are pharmacologically active. The psychoactive delta-9-tetrahydrocannabinol (THC) and the nonpsychoactive cannabidiol (CBD) are the most abundant phytocannabinoids and are present in different ratios depending on the plant strain. Other phytocannabinoids that have been less well studied to date include tetrahydrocannabivarin, cannabigerol, cannabichromene and cannabicyclol. The isolation of phytocannabinoids led to the identification of the biological targets by which they exert their effects, including the cannabinoid type $1(\mathrm{CB} 1)$ and type 2 (CB2) receptors. The discovery of endogenous ligands for these receptors, lipid messengers known as endocannabinoids, followed, and the best studied of these to date have been anandamide and 2arachidonoylglycerol (2-AG) [11•].

Cannabinoids have attracted considerable interest as candidate therapeutics for a range of neurological and psychiatric disorders due to the ubiquitous nature of endocannabinoid signalling and $\mathrm{CB} 1$ receptor expression throughout the brain [12, 13]. $\mathrm{CB} 1$ (and $\mathrm{CB} 2$ ) receptors and the other molecular mediators underlying endocannabinoid signalling are expressed in brain areas important for cognition, emotional regulation, defensive behaviours and their accompanying physiological responses (e.g. prefrontal cortex, hippocampus, amygdala, bed nucleus of stria terminalis, striatum, hypothalamus, periaqueductal grey, midbrain serotonergic and adrenergic nuclei), while both phytocannabinoids and endocannabinoids also act at various non-cannabinoid targets expressed in these areas (see below). Thus, cannabinoids are well placed to modulate the aberrant neural circuit dynamics that have been implicated in anxiety-related disorders $[2,11 \bullet, 14]$.

\section{Phytocannabinoid Regulation of Fear and Anxiety: the Case for Cannabidiol}

Although recreational cannabis use is rife worldwide, it can be associated with anxiety symptoms acutely [15]. In terms of the mechanism underlying this effect of cannabis, studies in healthy volunteers dating back several decades showed that THC and CBD have opposing effects on anxiety. THC is anxiogenic, but this effect is diminished when it is coadministered with CBD [16]. In contrast, CBD given alone has anxiolytic properties, particularly under circumstances or 
in response to stimuli which normally provoke anxiety. Both the anxiogenic and psychotropic effects of THC would appear to preclude its use for treating anxiety-related disorders, at least when administered on its own. However, the reported anxiolysis caused by CBD gave rise to a number of preclinical studies that investigated its effects in different rodent models of innate fear and anxiety-like behaviour (e.g. elevated plus maze, open field, light-dark test, predator exposure). The findings of these studies broadly confirmed the anxiolytic potential of CBD when given systemically or infused locally into various brain areas governing fear and anxiety [14]. Neuroimaging studies have shown that the anxiety-reducing effects of CBD are accompanied by altered blood flow to some of the homologous areas in humans [17-19]. CBD is devoid of abuse potential given its lack of rewarding effects [20-22]. It also has a favourable safety profile and was recently approved for the treatment of rare childhood seizure disorders $[23,24]$. This makes CBD an attractive candidate therapeutic for treating anxiety-related disorders.

Studies using preclinical models of relevance to anxietyrelated disorders characterized by abnormally strong and persistent fear memory (i.e. phobias, PTSD) have shown that CBD also regulates learned fear and its inhibition in different ways. During fear conditioning, a cue or context is paired with a noxious stimulus, resulting in the consolidation of an associative fear memory. Later cue presentation or context reexposure alone initially results in conditioned fear responding and can also destabilize the memory trace, requiring its reconsolidation to maintain or update the fear memory. Repeatedly presenting the cue or prolonged context reexposure also reduces fear responding through an inhibitory learning process known as extinction, which competes with the original memory to suppress fear responding and also forms the theoretical basis of exposure therapy. Reducing conditioned fear responding, disrupting reconsolidation and enhancing extinction are all potential strategies for acute or lasting symptom reduction in phobias and PTSD $[1,25]$.

Acute systemic CBD treatment or infusion of CBD into discrete areas of the fear circuit before or after conditioning reduces fear memory encoding [26-29], although the clinical relevance of interfering with the formation of fear memory is somewhat limited. CBD also reduces learned fear expression acutely when given systemically [30-33] or centrally into some [31, 34-36], but not all [31, 37], areas of the fear circuit. Reconsolidation is disrupted by CBD treatment after memory retrieval [38-40], while extinction is potentiated by CBD given systemically or centrally [33, 41-43], although these opposing effects of CBD both lead to reduced learned fear.

Given the wealth of preclinical evidence for the anxiolytic potential of CBD, it is perhaps not surprising that case reports and small-scale studies examining its effects in a range of anxiety-related disorders have recently emerged. Overall, their findings have indicated that $\mathrm{CBD}$ treatment provides symptom relief in these disorders [44-48]. However, it should be stressed that large-scale placebo-controlled studies are needed to confirm these preliminary, albeit encouraging, results.

A number of pharmacological mechanisms underpin the potential therapeutic effects of CBD generally [49], but its regulation of anxiety-like behaviour and learned fear processing involves 5-HT1A receptors, transient receptor potential vanilloid 1 (TRPV1) channels and endocannabinoid signalling. The acute effects of CBD given systemically on anxiety and learned fear expression have been shown to be dose-dependent, such that low and intermediate, but not high, doses are effective. These effects of low and intermediate doses of CBD are blocked by 5-HT1A receptor antagonists given systemically or locally into various relevant brain areas, whereas blocking TRPV1 receptors centrally allows for high doses of $\mathrm{CBD}$ to be effective. These results indicate that the anxiolytic effects of lower doses of CBD involve 5-HT1A receptor activation, whereas higher doses of CBD might not affect anxiety by also activating TRPV1 channels $[14,50]$.

In contrast to the acute anxiolytic effects of $\mathrm{CBD}$, its enhancement of extinction and disruption of fear memory consolidation and reconsolidation involve cannabinoid receptors. CBD-induced disruption of consolidation is blocked by CB1 and CB2 receptor antagonists infused centrally [28]. Disruption of reconsolidation by CBD is also blocked by systemic or central CB1 receptor antagonist treatment [38, 51]. Extinction enhancement by CBD is blocked by central CB1 receptor antagonism $[41,42]$. These results indicate that CBD regulation of learned fear processing is mediated at least in part by cannabinoid receptor activation. However, CBD shows little affinity for $\mathrm{CB} 1$ or $\mathrm{CB} 2$ receptors [52]. This suggests that its cannabinoid receptor-dependent effects on extinction and fear memory consolidation and reconsolidation occur indirectly by modulating endocannabinoid signalling, which we summarize below.

\section{Endocannabinoid Signalling: a Target for Regulating Fear and Anxiety}

As alluded to above, endocannabinoid signalling involves endocannabinoid activation of cannabinoid receptors and other non-cannabinoid targets. 2-AG and anandamide are the best characterized endocannabinoids, and they have differing affinities for these targets. 2-AG acts as a full agonist at CB1 and $\mathrm{CB} 2$ receptors, while anandamide has lower affinity for cannabinoid receptors but acts as a full agonist at TRPV1 receptors $[11 \bullet]$. Endocannabinoid signalling differs from that of classical neurotransmitters in that they are synthesized on demand in post-synaptic neurons in response to neuronal activation and act on their targets located presynaptically or in the postsynaptic neuron itself to mediate retrograde or non-retrograde signalling, respectively. During retrograde signalling, endocannabinoids act on presynaptic CB1 receptors to suppress 
neurotransmitter release from excitatory (i.e. glutamatergic) or inhibitory (i.e. GABAergic) neurons. This retrograde signalling is involved in different forms of short-term (i.e. depolarizationinduced suppression of excitation or inhibition) and long-term (i.e. homosynaptic glutamatergic or heterosynaptic GABAergic long-term depression) synaptic plasticity. During nonretrograde signalling, endocannabinoids act on post-synaptic cannabinoid receptors or TRPV1 channels. This nonretrograde signalling regulates self-inhibition via a CB1 and CB2 receptor-dependent reduction in excitability and also synaptic plasticity through a TRPV1-mediated form of long-term depression [53]. Endocannabinoid signalling is tightly regulated by transporters that remove endocannabinoids from the synapse and degradative enzymes that metabolize them. Monoacylglycerol lipase (MAGL) is found presynaptically and is the main enzyme responsible for metabolizing 2-AG, whereas fatty acid amide hydrolase (FAAH) is located postsynaptically and is the main enzyme that mediates anandamide degradation [54]. Other pathways are also involved in metabolizing endocannabinoids, with cyclooxygenase-2 (COX-2) degradation of anandamide and 2-AG $[55,56]$ recently implicated in regulating fear and anxiety (see below).

Endocannabinoid signalling is thus ideally positioned to modulate neuronal activity and synaptic plasticity in the fear and anxiety circuitry. Moreover, various gene variants associated with endocannabinoid transmission (e.g. FAAH, CB1 receptor) have been linked to anxiety-related disorders $[57-60,61 \bullet \bullet, 62]$. PTSD has also been associated with decreased 2-AG levels in the circulation, while anandamide levels were related to certain PTSD symptoms [63, 64]. However, other evidence has shown increased endocannabinoid levels in PTSD [65]. Nevertheless, pharmacological manipulation of endocannabinoid signalling at the level of cannabinoid receptors, transporters and degradative enzymes is a potential strategy for regulating fear and anxiety.

In terms of the cannabinoid receptor-dependent effects of $\mathrm{CBD}$ on learned fear regulation described above, CBD increases anandamide levels by inhibiting its transportermediated reuptake and degradation by FAAH [66]. CBD also binds to the fatty acid binding proteins that transport anandamide intracellularly to FAAH for its degradation, which may play a role in the inhibition of anandamide metabolism by CBD. There is also evidence that CBD reduces MAGLmediated degradation of 2-AG [67, 68]. However, whether these putative mechanisms are involved in CBD regulation of learned fear processing remains to be confirmed.

CB1 receptor agonists can have both anxiolytic and anxiogenic effects, depending on the dose, route of administration, differences in CB1 receptor sensitivity in different brain areas and the aversive nature of the behavioural testing paradigm used [69]. As is the case with CBD, anandamide has been shown to be anxiolytic at lower doses and anxiogenic at higher doses, with the former effect involving CB1 receptor activation and the latter effect involving TRPV1 channel activation [70]. This indicates that maintaining the balance between $\mathrm{CB} 1$ receptor and TRPV1 channel activation is crucial for regulating anxiety, given their opposing anxiolytic and anxiogenic effects [71-73].

Elevating anandamide levels systemically or centrally via the pharmacological inhibition of FAAH is well known to produce anxiolysis, particularly under more aversive conditions [74]. In contrast, the effects of inhibiting MAGL to potentiate 2-AG levels have not been as well characterized and the results to date have been less clear. Most studies have shown that increasing 2AG levels by inhibiting MAGL has anxiolytic effects but some have shown no or even anxiogenic effects of MAGL inhibition [74-77]. Interestingly, a recent study showed anxiolytic effects of FAAH or MAGL inhibition but not with a dual FAAH/MAGL inhibitor [78]. COX-2 inhibition, which is better known for its anti-inflammatory effects by interfering with prostaglandin synthesis, is also associated with endocannabinoiddependent anxiolysis. This has been demonstrated using substrate-selective COX-2 inhibitors that prevent the degradation of endocannabinoids without affecting prostaglandin synthesis [79]. However, other evidence indicates that the anxiolytic effect of a different substrate-specific COX-2 inhibitor occurred in an endocannabinoid-independent manner [80].

In terms of endocannabinoid regulation of learned fear processing, a seminal study by Marsicano et al. (2003) provided compelling evidence that endocannabinoid signalling via CB1 receptors is crucial for fear extinction. CB1 receptor-deficient mice, or wild-type controls given a CB1 receptor antagonist, showed impaired fear extinction. Endocannabinoid levels were found to be elevated by extinction and also played a crucial role in modulating synaptic plasticity in the fear circuit in a CB1 receptor-dependent manner [81]. Subsequent studies have added to these findings by showing that genetic variants of FAAH resulting in elevated anandamide levels also enhance fear extinction [59, 82•]. Moreover, pharmacological FAAH inhibitors were found to enhance fear extinction in a CB1 receptor-dependent manner [41, 83-89], although the involvement of $\mathrm{CB} 2$ receptors in mediating anandamide regulation of fear extinction has not been characterized. In contrast to FAAH, genetic or pharmacological inhibition of MAGL impairs fear extinction [90, 91], suggesting opposing roles for anandamide and 2-AG in modulating fear extinction.

Endocannabinoid signalling has also been implicated in the consolidation and reconsolidation of fear memory. Inhibiting FAAH or MAGL to elevate anandamide or 2-AG levels was shown to enhance fear memory consolidation $[92,93]$, while FAAH inhibition also modulates the consolidation of stronger memory associated with fear generalization [28]. These effects likely involve both CB1 [86, 94-98] and CB2 [93, 99-101] receptor signalling. Fear memory reconsolidation is also modulated by endocannabinoid signalling as FAAH inhibition enhances the reconsolidation of fear memory [102]. However, the role of cannabinoid receptors in mediating this 
effect appears to be complex given that both agonists and antagonists have been shown to impair fear memory reconsolidation [85, 97, 102-104]. Post-retrieval fear memory destabilization, which is required to make reconsolidation of the fear memory trace amenable to pharmacological disruption, is enhanced by CB1 receptor activation [105, 106]. However, the involvement of MAGL/2-AG and CB2 receptor signalling in regulating the reconsolidation of fear memory remains to be elucidated.

\section{Conclusions}

The evidence reviewed above demonstrates the potential utility of the phytocannabinoid cannabidiol and pharmacological inhibitors of FAAH, to elevate levels of the endocannabinoid anandamide, for the treatment of anxiety-related disorders in the future. Such cannabinoid-related medicines could be used in various ways to treat these disorders. Given their acute anxiolytic effects, cannabidiol and FAAH inhibitors could be used as adjuncts to first-line SSRI or SNRI treatment, which have a delayed therapeutic response. Such drugs could be an improvement over benzodiazepines, which have abuse liability, a less favourable side effect profile and can interfere with extinction, which forms the theoretical basis for exposure therapy used in the psychological treatment of certain anxiety-related disorders $[1,10]$. In this respect, cannabinoids could be combined with existing or novel psychological therapies to facilitate extinction enhancement and/ or fear memory reconsolidation disruption, both of which may result in a lasting reduction of fear. Cannabinoid-related medicines could also be given as anxiolytics on their own but further research is needed to determine their effects when given repeatedly as the few studies that have examined this issue have found mixed results [107-110]. The potential for certain adverse effects should also be examined more thoroughly given the reports of cannabinoid use being linked to executive dysfunction [111, 112]. Nevertheless, based on the evidence reviewed here, further research on cannabinoid regulation of fear and anxiety appears to be warranted and below we suggest various lines of enquiry for future work in this area.

The effects of these cannabinoids in other paradigms or measures of learned fear, and its return after extinction, should be characterized to determine if their reported anxiolytic effects are enduring and more widely applicable [28, 89, 113]. In terms of the pharmacological mechanisms underlying the indirect cannabinoid receptor-dependent effects of CBD on extinction and fear memory reconsolidation, further research is needed to determine which endocannabinoid or endocannabinoids are involved. The possibility that CB2 receptor signalling is involved in mediating the effects of CBD and anandamide should also be examined. This is because $\mathrm{CB} 2$ receptor activation might avoid the psychotropic effects associated with activating CB1 receptors [114], which also likely rules out the feasibility of using full CB1 receptor agonists for treating anxiety-related disorders. The synaptic plasticity mechanisms underlying the effects of cannabidiol and anandamide on extinction and fear memory reconsolidation, which might involve both cannabinoid receptor and TRPV1 signalling [115], also remain to be fully elucidated. Given the opposing roles of cannabinoid receptor and TRPV1 activation in regulating anxiety, novel drugs combining cannabinoid receptor agonist and TRPV1 antagonist properties may have synergistic anxiolytic effects [116]. Cannabinoids modulate the function of other neurotransmitters (e.g. 5-HT, noradrenaline, GABA) that underpin the therapeutic effects of currently available anxiolytic medications; therefore, understanding the relevant mechanisms involved may also lead to novel insights on the neurobiology of anxiety-related disorders [117, 118].

At the outset, we noted that the availability of phytocannabinoids and their use for self-medication in various anxiety-related disorders have recently become more commonplace. The anxiogenic effects linked to recreational cannabis use [15] likely involve a relatively high THC and low CBD content, but cannabis strains with different ratios of THC:CBD may have a more favourable anxiolytic profile. Interestingly, this could be investigated by systematically characterizing the effects of Sativex, a cannabis-derived extract with a $\sim 1: 1$ ratio of THC and CBD that is already approved for clinical use to treat spasticity in multiple sclerosis, on anxiety and learned fear processing [119, 120]. "Pure" cannabidiol has also recently been approved for clinical use as Epidiolex for treating rare seizure disorders in children, which could facilitate its eventual use in treating anxiety-related disorders. Cannabis contains a plethora of other pharmacologically active phytocannabinoids that may also regulate fear and anxiety, but their effects have yet to be determined in relevant preclinical models.

Acknowledgements We thank Christine Stubbendorff for her insightful comments on the manuscript.

Funding Information Eleni P. Papagianni was supported by an Industrial CASE PhD studentship from the Biotechnology and Biological Sciences Research Council (grant number BB/M008770/1), which was cosponsored by Artelo Biosciences.

\section{Compliance with Ethical Standards}

Conflict of Interest Eleni P. Papagianni's PhD studentship was funded in part by Artelo Biosciences, a biopharmaceutical company with interests in the development and commercialization of cannabinoid-based medicines. Artelo Biosciences had no involvement in any aspect of this review. Carl W. Stevenson declares no potential conflict of interest.

Human and Animal Rights and Informed Consent All reported studies/ experiments with human or animal subjects performed by the authors have been previously published and complied with all applicable ethical standards (including the Helsinki declaration and its amendments, institutional/national research committee standards, and international/national/institutional guidelines). 
Open Access This article is distributed under the terms of the Creative Commons Attribution 4.0 International License (http:// creativecommons.org/licenses/by/4.0/), which permits unrestricted use, distribution, and reproduction in any medium, provided you give appropriate credit to the original author(s) and the source, provide a link to the Creative Commons license, and indicate if changes were made.

\section{References}

Papers of particular interest, published recently, have been highlighted as:

- Of importance

•- Of major importance

1. Singewald N, Schmuckermair C, Whittle N, Holmes A, Ressler KJ. Pharmacology of cognitive enhancers for exposure-based therapy of fear, anxiety and trauma-related disorders. Pharmacol Ther. 2015;149:150-90. https://doi.org/10.1016/j.pharmthera. 2014.12.004.

2. Tovote P, Fadok JP, Luthi A. Neuronal circuits for fear and anxiety. Nat Rev Neurosci. 2015;16:317-31. https://doi.org/10.1038/ nrn3945.

3. Bandelow B, Michaelis S. Epidemiology of anxiety disorders in the 21st century. Dialogues Clin Neurosci. 2015;17:327-35.

4. Craske MG, Stein MB, Eley TC, Milad MR, Holmes A, Rapee RM, et al. Anxiety disorders. Nat Rev Dis Primers. 2017;3:17024. https://doi.org/10.1038/nrdp.2017.24 A useful primer on anxiety-related disorders.

5. Hendriks SM, Spijker J, Licht CMM, Hardeveld F, de Graaf R, Batelaan NM, et al. Long-term disability in anxiety disorders. BMC Psychiatry. 2016;16:248. https://doi.org/10.1186/s12888016-0946-y.

6. Tipps ME, Raybuck JD, Lattal KM. Substance abuse, memory, and post-traumatic stress disorder. Neurobiol Learn Mem. 2014;112:87-100. https://doi.org/10.1016/j.nlm.2013.12.002.

7. Watkins LE, Sprang KR, Rothbaum BO. Treating PTSD: a review of evidence-based psychotherapy interventions. Front Behav Neurosci. 2018;12:258. https://doi.org/10.3389/fnbeh.2018. 00258.

8. Murrough JW, Yaqubi S, Sayed S, Charney DS. Emerging drugs for the treatment of anxiety. Expert Opin Emerg Drugs. 2015;20: 393-406. https://doi.org/10.1517/14728214.2015.1049996.

9. Bystritsky A, Khalsa SS, Cameron ME, Schiffman J. Current diagnosis and treatment of anxiety disorders. P T. 2013;38:30-57.

10. Guina J, Rossetter SR, DeRhodes BJ, Nahhas RW, Welton RS. Benzodiazepines for PTSD: a systematic review and meta-analysis. J Psychiatr Pract. 2015;21:281-303. https://doi.org/10.1097/ pra.0000000000000091.

11. Ligresti A, Petrocellis LD, Marzo VD. From phytocannabinoids to cannabinoid receptors and endocannabinoids: pleiotropic physiological and pathological roles through complex pharmacology. Physiol Rev 2016;96:1593-1659. doi:https://doi.org/10.1152/ physrev.00002. 2016. A comprehensive review of cannabinoid receptor signalling.

12. Russo EB. Cannabis therapeutics and the future of neurology. Front Integr Neurosci. 2018;12:51. https://doi.org/10.3389/fnint. 2018.00051.

13. Scherma M, Masia P, Deidda M, Fratta W, Tanda G, Fadda P. New perspectives on the use of cannabis in the treatment of psychiatric disorders. Medicines (Basel). 2018;5(4). https://doi.org/10.3390/ medicines5040107.
14. Lee JLC, Bertoglio LJ, Guimaraes FS, Stevenson CW. Cannabidiol regulation of emotion and emotional memory processing: relevance for treating anxiety-related and substance abuse disorders. Br J Pharmacol. 2017;174:3242-56. https://doi. org/10.1111/bph.13724.

15. Crippa JA, Zuardi AW, Martin-Santos R, Bhattacharyya S, Atakan $\mathrm{Z}$, McGuire P, et al. Cannabis and anxiety: a critical review of the evidence. Hum Psychopharmacol. 2009;24:515-23. https://doi. org/10.1002/hup.1048.

16. Zuardi AW, Shirakawa I, Finkelfarb E, Karniol IG. Action of cannabidiol on the anxiety and other effects produced by delta 9-THC in normal subjects. Psychopharmacology. 1982;76:24550.

17. Crippa JA, Zuardi AW, Garrido GE, Wichert-Ana L, Guarnieri R, Ferrari L, et al. Effects of cannabidiol (CBD) on regional cerebral blood flow. Neuropsychopharmacology. 2004;29:417-26. https:// doi.org/10.1038/sj.npp.1300340.

18. Fusar-Poli P, Crippa JA, Bhattacharyya S, Borgwardt SJ, Allen P, Martin-Santos R, et al. Distinct effects of \{delta\}9-tetrahydrocannabinol and cannabidiol on neural activation during emotional processing. Arch Gen Psychiatry. 2009;66:95-105. https://doi. org/10.1001/archgenpsychiatry.2008.519.

19. Fusar-Poli P, Allen P, Bhattacharyya S, Crippa JA, Mechelli A, Borgwardt S, et al. Modulation of effective connectivity during emotional processing by Delta 9-tetrahydrocannabinol and cannabidiol. Int J Neuropsychopharmacol. 2010;13:421-32. https://doi.org/10.1017/s1461145709990617.

20. Parker LA, Burton P, Sorge RE, Yakiwchuk C, Mechoulam R. Effect of low doses of delta9-tetrahydrocannabinol and cannabidiol on the extinction of cocaine-induced and amphetamine-induced conditioned place preference learning in rats. Psychopharmacology. 2004;175:360-6. https://doi.org/10.1007/ s00213-004-1825-7.

21. Vann RE, Gamage TF, Warner JA, Marshall EM, Taylor NL, Martin BR, et al. Divergent effects of cannabidiol on the discriminative stimulus and place conditioning effects of Delta(9)-tetrahydrocannabinol. Drug Alcohol Depend. 2008;94:191-8. https:// doi.org/10.1016/j.drugalcdep.2007.11.017.

22. Katsidoni V, Anagnostou I, Panagis G. Cannabidiol inhibits the reward-facilitating effect of morphine: involvement of 5-HT1A receptors in the dorsal raphe nucleus. Addict Biol. 2013;18:28696. https://doi.org/10.1111/j.1369-1600.2012.00483.x.

23. Iffland K, Grotenhermen F. An update on safety and side effects of cannabidiol: a review of clinical data and relevant animal studies. Cannabis Cannabinoid Res. 2017;2:139-54. https://doi.org/10. 1089/can.2016.0034.

24. Billakota S, Devinsky O, Marsh E. Cannabinoid therapy in epilepsy. Curr Opin Neurol. 2019;32:220-6. https://doi.org/10.1097/ wco.0000000000000660.

25. Lee JLC, Nader K, Schiller D. An update on memory reconsolidation updating. Trends Cogn Sci. 2017;21:531-45. https://doi.org/10.1016/j.tics.2017.04.006.

26. Levin R, Almeida V, Peres FF, Calzavara MB, da Silva ND, Suiama MA, et al. Antipsychotic profile of cannabidiol and rimonabant in an animal model of emotional context processing in schizophrenia. Curr Pharm Des. 2012;18:4960-5.

27. Norris C, Loureiro M, Kramar C, Zunder J, Renard J, Rushlow W, et al. Cannabidiol modulates fear memory formation through interactions with serotonergic transmission in the mesolimbic system. Neuropsychopharmacology. 2016;41:2839-50. https://doi. org/10.1038/npp.2016.93.

28. Stern CAJ, da Silva TR, Raymundi AM, de Souza CP, HiroakiSato VA, Kato L, et al. Cannabidiol disrupts the consolidation of specific and generalized fear memories via dorsal hippocampus CB1 and CB2 receptors. Neuropharmacology. 2017;125:220-30. https://doi.org/10.1016/j.neuropharm.2017.07.024. 
29. Rossignoli MT, Lopes-Aguiar C, Ruggiero RN, Do Val da Silva RA, Bueno-Junior LS, Kandratavicius L, et al. Selective posttraining time window for memory consolidation interference of cannabidiol into the prefrontal cortex: reduced dopaminergic modulation and immediate gene expression in limbic circuits. Neuroscience. 2017;350:85-93. https://doi.org/10.1016/j. neuroscience.2017.03.019.

30. Resstel LB, Joca SR, Moreira FA, Correa FM, Guimaraes FS. Effects of cannabidiol and diazepam on behavioral and cardiovascular responses induced by contextual conditioned fear in rats. Behav Brain Res. 2006;172:294-8. https://doi.org/10.1016/j.bbr. 2006.05.016.

31. Lemos JI, Resstel LB, Guimaraes FS. Involvement of the prelimbic prefrontal cortex on cannabidiol-induced attenuation of contextual conditioned fear in rats. Behav Brain Res. 2010;207:105-11. https://doi.org/10.1016/j.bbr.2009.09.045.

32. Jurkus R, Day HLL, Guimarães FS, Lee JLC, Bertoglio LJ, Stevenson CW. Cannabidiol regulation of learned fear: implications for treating anxiety-related disorders. Front Pharmacol. 2016;7:454. https://doi.org/10.3389/fphar.2016.00454.

33. Song C, Stevenson CW, Guimaraes FS, Lee JL. Bidirectional effects of cannabidiol on contextual fear memory extinction. Front Pharmacol. 2016;7:493. https://doi.org/10.3389/fphar. 2016.00493.

34. Gomes FV, Resstel LB, Guimaraes FS. The anxiolytic-like effects of cannabidiol injected into the bed nucleus of the stria terminalis are mediated by 5-HT1A receptors. Psychopharmacology. 2011;213:465-73. https://doi.org/10.1007/s00213-010-2036-z.

35. Gomes FV, Reis DG, Alves FH, Correa FM, Guimaraes FS, Resstel LB. Cannabidiol injected into the bed nucleus of the stria terminalis reduces the expression of contextual fear conditioning via 5-HT1A receptors. J Psychopharmacol. 2012;26:104-13. https://doi.org/10.1177/0269881110389095.

36. Fogaca MV, Reis FM, Campos AC, Guimaraes FS. Effects of intra-prelimbic prefrontal cortex injection of cannabidiol on anxiety-like behavior: involvement of 5HT1A receptors and previous stressful experience. Eur Neuropsychopharmacol. 2014;24: 410-9. https://doi.org/10.1016/j.euroneuro.2013.10.012.

37. Marinho AL, Vila-Verde C, Fogaca MV, Guimaraes FS. Effects of intra-infralimbic prefrontal cortex injections of cannabidiol in the modulation of emotional behaviors in rats: contribution of 5HT(1)A receptors and stressful experiences. Behav Brain Res. 2015;286:49-56. https://doi.org/10.1016/j.bbr.2015.02.023.

38. Stern CA, Gazarini L, Takahashi RN, Guimaraes FS, Bertoglio LJ. On disruption of fear memory by reconsolidation blockade: evidence from cannabidiol treatment. Neuropsychopharmacology. 2012;37:2132-42. https://doi.org/10.1038/npp.2012.63.

39. Stern CAJ, Gazarini L, Vanvossen AC, Zuardi AW, Galve-Roperh I, Guimaraes FS, et al. $\Delta$ 9-Tetrahydrocannabinol alone and combined with cannabidiol mitigate fear memory through reconsolidation disruption. Eur Neuropsychopharmacol. 2015;25:958-65. https://doi.org/10.1016/j.euroneuro.2015.02. 001 .

40. Gazarini L, Stern CA, Piornedo RR, Takahashi RN, Bertoglio LJ. PTSD-like memory generated through enhanced noradrenergic activity is mitigated by a dual step pharmacological intervention targeting its reconsolidation. Int $\mathrm{J}$ Neuropsychopharmacol. 2015;18:pyu026. https://doi.org/10.1093/ijnp/pyu026.

41. Bitencourt RM, Pamplona FA, Takahashi RN. Facilitation of contextual fear memory extinction and anti-anxiogenic effects of AM404 and cannabidiol in conditioned rats. Eur Neuropsychopharmacol. 2008;18:849-59. https://doi.org/10. 1016/j.euroneuro.2008.07.001.

42. Do Monte FH, Souza RR, Bitencourt RM, Kroon JA, Takahashi $\mathrm{RN}$. Infusion of cannabidiol into infralimbic cortex facilitates fear extinction via CB1 receptors. Behav Brain Res. 2013;250:23-7. https://doi.org/10.1016/j.bbr.2013.04.045.

43. Das RK, Kamboj SK, Ramadas M, Yogan K, Gupta V, Redman E, et al. Cannabidiol enhances consolidation of explicit fear extinction in humans. Psychopharmacology. 2013;226:781-92. https:// doi.org/10.1007/s00213-012-2955-y.

44. Bergamaschi MM, Queiroz RH, Chagas MH, de Oliveira DC, De Martinis BS, Kapczinski F, et al. Cannabidiol reduces the anxiety induced by simulated public speaking in treatment-naive social phobia patients. Neuropsychopharmacology. 2011;36:1219-26. https://doi.org/10.1038/npp.2011.6.

45. Crippa JA, Derenusson GN, Ferrari TB, Wichert-Ana L, Duran FL, Martin-Santos R, et al. Neural basis of anxiolytic effects of cannabidiol (CBD) in generalized social anxiety disorder: a preliminary report. J Psychopharmacol. 2011;25:121-30. https://doi. org/10.1177/0269881110379283.

46. Shannon S, Opila-Lehman J. Effectiveness of cannabidiol oil for pediatric anxiety and insomnia as part of posttraumatic stress disorder: a case report. Perm J. 2016;20:108-11. https://doi.org/10. 7812/tpp/16-005.

47. Elms L, Shannon S, Hughes S, Lewis N. Cannabidiol in the treatment of post-traumatic stress disorder: a case series. J Altern Complement Med. 2018. https://doi.org/10.1089/acm.2018.0437.

48. Shannon S, Lewis N, Lee H, Hughes S. Cannabidiol in anxiety and sleep: a large case series. Perm J. 2019;23:18-041. https://doi. org/10.7812/TPP/18-041.

49. Ibeas Bih C, Chen T, Nunn AV, Bazelot M, Dallas M, Whalley BJ. Molecular targets of cannabidiol in neurological disorders. Neurotherapeutics. 2015;12:699-730. https://doi.org/10.1007/ s13311-015-0377-3.

50. Campos AC, Guimaraes FS. Evidence for a potential role for TRPV1 receptors in the dorsolateral periaqueductal gray in the attenuation of the anxiolytic effects of cannabinoids. Prog Neuro-Psychopharmacol Biol Psychiatry. 2009;33:1517-21. https://doi.org/10.1016/j.pnpbp.2009.08.017.

51. Stern CA, Gazarmi L, Vanvossen AC, Zuardi AW, Guimarães FS, Takahashi RN, Bertoglio LJet al. P.1.j.006 Involvement of the prelimbic cortex in the disruptive effect of cannabidiol on fear memory reconsolidation. Eur Neuropsychopharmacol 2014;24: S322. doi:https://doi.org/10.1016/S0924-977X(14)70511-5.

52. Hanus LO, Tchilibon S, Ponde DE, Breuer A, Fride E, Mechoulam R. Enantiomeric cannabidiol derivatives: synthesis and binding to cannabinoid receptors. Org Biomol Chem. 2005;3:1116-23. https://doi.org/10.1039/b416943c.

53. Castillo Pablo E, Younts Thomas J, Chávez Andrés E, Hashimotodani Y. Endocannabinoid signaling and synaptic function. Neuron. 2012;76:70-81. https://doi.org/10.1016/j.neuron. 2012.09.020.

54. Ahn K, McKinney MK, Cravatt BF. Enzymatic pathways that regulate endocannabinoid signaling in the nervous system. Chem Rev. 2008;108:1687-707. https://doi.org/10.1021/ cr0782067.

55. Urquhart P, Nicolaou A, Woodward DF. Endocannabinoids and their oxygenation by cyclo-oxygenases, lipoxygenases and other oxygenases. Biochim Biophys Acta. 2015;1851:366-76. https:// doi.org/10.1016/j.bbalip.2014.12.015.

56. Maccarrone M. Metabolism of the endocannabinoid anandamide: open questions after 25 years. Front Mol Neurosci. 2017;10:166. https://doi.org/10.3389/fnmol.2017.00166.

57. Lazary J, Lazary A, Gonda X, Benko A, Molnar E, Hunyady L, et al. Promoter variants of the cannabinoid receptor 1 gene (CNR1) in interaction with 5-HTTLPR affect the anxious phenotype. Am J Med Genet B Neuropsychiatr Genet. 2009;150B: 1118-27. https://doi.org/10.1002/ajmg.b.31024.

58. Lazary J, Eszlari N, Juhasz G, Bagdy G. Genetically reduced FAAH activity may be a risk for the development of anxiety and 
depression in persons with repetitive childhood trauma. Eur Neuropsychopharmacol. 2016;26:1020-8. https://doi.org/10. 1016/j.euroneuro.2016.03.003.

59. Dincheva I, Drysdale AT, Hartley CA, Johnson DC, Jing D, King EC, et al. FAAH genetic variation enhances fronto-amygdala function in mouse and human. Nat Commun. 2015;6:6395. https://doi.org/10.1038/ncomms7395.

60. Demers CH, Drabant Conley E, Bogdan R, Hariri AR. Interactions between anandamide and corticotropin-releasing factor signaling modulate human amygdala function and risk for anxiety disorders: an imaging genetics strategy for modeling molecular interactions. Biol Psychiatry. 2016;80:356-62. https://doi. org/10.1016/j.biopsych.2015.12.021.

61.• Gee DG, Fetcho RN, Jing D, Li A, Glatt CE, Drysdale AT, et al. Individual differences in frontolimbic circuitry and anxiety emerge with adolescent changes in endocannabinoid signaling across species. PNAS. 2016;113:4500-5. https://doi.org/10. 1073/pnas.1600013113 Cross-species study demonstrating important links between FAAH polymorphism, frontolimbic circuit connectivity, and anxiety-related behavior.

62. Lester KJ, Coleman JR, Roberts S, Keers R, Breen G, Bogels S, et al. Genetic variation in the endocannabinoid system and response to cognitive behavior therapy for child anxiety disorders. Am J Med Genet B Neuropsychiatr Genet. 2017;174:144-55. https://doi.org/10.1002/ajmg.b.32467.

63. Hill MN, Bierer LM, Makotkine I, Golier JA, Galea S, McEwen BS, et al. Reductions in circulating endocannabinoid levels in individuals with post-traumatic stress disorder following exposure to the World Trade Center attacks. Psychoneuroendocrinology. 2013;38:2952-61. https://doi.org/10.1016/j.psyneuen.2013.08. 004 .

64. Neumeister A, Normandin MD, Pietrzak RH, Piomelli D, Zheng $\mathrm{MQ}$, Gujarro-Anton A, et al. Elevated brain cannabinoid CB1 receptor availability in post-traumatic stress disorder: a positron emission tomography study. Mol Psychiatry. 2013;18:1034-40. https://doi.org/10.1038/mp.2013.61.

65. Hauer D, Schelling G, Gola H, Campolongo P, Morath J, Roozendaal B, et al. Plasma concentrations of endocannabinoids and related primary fatty acid amides in patients with posttraumatic stress disorder. PLoS One. 2013;8:e62741. https://doi. org/10.1371/journal.pone.0062741.

66. Bisogno T, Maccarrone M. Latest advances in the discovery of fatty acid amide hydrolase inhibitors. Expert Opin Drug Discovery. 2013;8:509-22. https://doi.org/10.1517/17460441. 2013.780021.

67. De Petrocellis L, Ligresti A, Moriello AS, Allara M, Bisogno T, Petrosino S, et al. Effects of cannabinoids and cannabinoidenriched Cannabis extracts on TRP channels and endocannabinoid metabolic enzymes. Br J Pharmacol. 2011;163: 1479-94. https://doi.org/10.1111/j.1476-5381.2010.01166.x.

68. Elmes MW, Kaczocha M, Berger WT, Leung K, Ralph BP, Wang L, et al. Fatty acid-binding proteins (FABPs) are intracellular carriers for Delta9-tetrahydrocannabinol (THC) and cannabidiol (CBD). J Biol Chem. 2015;290:8711-21. https://doi.org/10. 1074/jbc.M114.618447.

69. Korem N, Zer-Aviv TM, Ganon-Elazar E, Abush H, Akirav I. Targeting the endocannabinoid system to treat anxiety-related disorders. J Basic Clin Physiol Pharmacol. 2016;27:193-202. https:// doi.org/10.1515/jbcpp-2015-0058.

70. Batista PA, Fogaca MV, Guimaraes FS. The endocannabinoid, endovanilloid and nitrergic systems could interact in the rat dorsolateral periaqueductal gray matter to control anxiety-like behaviors. Behav Brain Res. 2015;293:182-8. https://doi.org/10.1016/j. bbr.2015.07.019.

71. Uliana DL, Hott SC, Lisboa SF, Resstel LB. Dorsolateral periaqueductal gray matter CB1 and TRPV1 receptors exert opposite modulation on expression of contextual fear conditioning. Neuropharmacology. 2016;103:257-69. https://doi.org/10. 1016/j.neuropharm.2015.12.020.

72. Faraji N, Komaki A, Salehi I. Interaction between the cannabinoid and vanilloid systems on anxiety in male rats. Basic Clin Neurosci. 2017;8:129-37. https://doi.org/10.18869/nirp.ben.8.2.129.

73. Back FP, Carobrez AP. Periaqueductal gray glutamatergic, cannabinoid and vanilloid receptor interplay in defensive behavior and aversive memory formation. Neuropharmacology. 2018;135:399 411. https://doi.org/10.1016/j.neuropharm.2018.03.032.

74. Patel S, Hill MN, Cheer JF, Wotjak CT, Holmes A. The endocannabinoid system as a target for novel anxiolytic drugs. Neurosci Biobehav Rev. 2017;76(Pt A:56-66. https://doi.org/ 10.1016/j.neubiorev.2016.12.033.

75. Lomazzo E, Bindila L, Remmers F, Lerner R, Schwitter C, Hoheisel U, et al. Therapeutic potential of inhibitors of endocannabinoid degradation for the treatment of stress-related hyperalgesia in an animal model of chronic pain. Neuropsychopharmacology. 2015;40:488-501. https://doi.org/ 10.1038/npp.2014.198.

76. Llorente-Berzal A, Terzian AL, di Marzo V, Micale V, Viveros MP, Wotjak CT. 2-AG promotes the expression of conditioned fear via cannabinoid receptor type 1 on GABAergic neurons. Psychopharmacology. 2015;232:2811-25. https://doi.org/10. 1007/s00213-015-3917-y.

77. Morena M, Leitl KD, Vecchiarelli HA, Gray JM, Campolongo P, Hill MN. Emotional arousal state influences the ability of amygdalar endocannabinoid signaling to modulate anxiety. Neuropharmacology. 2016;111:59-69. https://doi.org/10.1016/j. neuropharm.2016.08.020.

78. Bedse G, Bluett RJ, Patrick TA, Romness NK, Gaulden AD, Kingsley PJ, et al. Therapeutic endocannabinoid augmentation for mood and anxiety disorders: comparative profiling of FAAH, MAGL and dual inhibitors. Transl Psychiatry. 2018;8:92. https:// doi.org/10.1038/s41398-018-0141-7.

79. Hermanson DJ, Hartley ND, Gamble-George J, Brown N, Shonesy BC, Kingsley PJ, et al. Substrate-selective COX-2 inhibition decreases anxiety via endocannabinoid activation. Nat Neurosci. 2013;16:1291-8. https://doi.org/10.1038/nn.3480.

80. Gamble-George JC, Baldi R, Halladay L, Kocharian A, Hartley N, Silva CG et al. Cyclooxygenase-2 inhibition reduces stressinduced affective pathology. eLife 2016;5:e14137. doi:https:// doi.org/10.7554/eLife.14137.

81. Marsicano G, Wotjak CT, Azad SC, Bisogno T, Rammes G, Cascio MG, et al. The endogenous cannabinoid system controls extinction of aversive memories. Nature. 2002;418:530-4. https:// doi.org/10.1038/nature00839.

82. Mayo LM, Asratian A, Linde J, Holm L, Natt D, Augier G, et al. Protective effects of elevated anandamide on stress and fearrelated behaviors: translational evidence from humans and mice. Mol Psychiatry. 2018. https://doi.org/10.1038/s41380-018-02151 Cross-species study demonstrating important links between FAAH polymorphism, anandamide levels, and stress resilience.

83. Suzuki A, Josselyn SA, Frankland PW, Masushige S, Silva AJ, Kida S. Memory reconsolidation and extinction have distinct temporal and biochemical signatures. J Neurosci. 2004;24:4787-95. https://doi.org/10.1523/jneurosci.5491-03.2004.

84. Pamplona FA, Bitencourt RM, Takahashi RN. Short- and longterm effects of cannabinoids on the extinction of contextual fear memory in rats. Neurobiol Learn Mem. 2008;90:290-3. https:// doi.org/10.1016/j.nlm.2008.04.003.

85. De Oliveira Alvares L, Genro BP, Diehl F, Quillfeldt JA. Differential role of the hippocampal endocannabinoid system in the memory consolidation and retrieval mechanisms. Neurobiol 
Learn Mem. 2008;90:1-9. https://doi.org/10.1016/j.nlm.2008.01. 009.

86. Kuhnert S, Meyer C, Koch M. Involvement of cannabinoid receptors in the amygdala and prefrontal cortex of rats in fear learning, consolidation, retrieval and extinction. Behav Brain Res. 2013;250:274-84. https://doi.org/10.1016/j.bbr.2013.05.002.

87. Gunduz-Cinar O, MacPherson KP, Cinar R, Gamble-George J, Sugden K, Williams B, et al. Convergent translational evidence of a role for anandamide in amygdala-mediated fear extinction, threat processing and stress-reactivity. Mol Psychiatry. 2013;18: 813-23. https://doi.org/10.1038/mp.2012.72.

88. Zubedat S, Akirav I. The involvement of cannabinoids and mTOR in the reconsolidation of an emotional memory in the hippocampal-amygdala-insular circuit. Eur Neuropsychopharmacol. 2017;27:336-49. https://doi.org/10. 1016/j.euroneuro.2017.01.011.

89. Segev A, Korem N, Mizrachi Zer-Aviv T, Abush H, Lange R, Sauber G, et al. Role of endocannabinoids in the hippocampus and amygdala in emotional memory and plasticity. Neuropsychopharmacology. 2018;43:2017-27. https://doi.org/ 10.1038/s41386-018-0135-4.

90. Kishimoto Y, Cagniard B, Yamazaki M, Nakayama J, Sakimura $\mathrm{K}$, Kirino Y, et al. Task-specific enhancement of hippocampusdependent learning in mice deficient in monoacylglycerol lipase, the major hydrolyzing enzyme of the endocannabinoid 2arachidonoylglycerol. Front Behav Neurosci. 2015;9:134. https://doi.org/10.3389/fnbeh.2015.00134.

91. Hartley ND, Gunduz-Cinar O, Halladay L, Bukalo O, Holmes A, Patel S. 2-arachidonoylglycerol signaling impairs short-term fear extinction. Transl Psychiatry 2016;6:e749-e. doi:https://doi.org/ 10.1038/tp.2016.26.

92. Morena M, Roozendaal B, Trezza V, Ratano P, Peloso A, Hauer D, et al. Endogenous cannabinoid release within prefrontal-limbic pathways affects memory consolidation of emotional training. PNAS. 2014;111:18333-8. https://doi.org/10.1073/pnas. 1420285111.

93. Ratano P, Petrella C, Forti F, Passeri PP, Morena M, Palmery M, et al. Pharmacological inhibition of 2-arachidonoilglycerol hydrolysis enhances memory consolidation in rats through $\mathrm{CB} 2$ receptor activation and mTOR signaling modulation. Neuropharmacology. 2018;138:210-8. https://doi.org/10.1016/j.neuropharm.2018.05. 030

94. de Oliveira Alvares L, de Oliveira LF, Camboim C, Diehl F, Genro BP, Lanziotti VB, et al. Amnestic effect of intrahippocampal AM251, a CB1-selective blocker, in the inhibitory avoidance, but not in the open field habituation task, in rats. Neurobiol Learn Mem. 2005;83:119-24. https://doi.org/10.1016/j.nlm. 2004.10.002.

95. de Oliveira Alvares L, Engelke DS, Diehl F, Scheffer-Teixeira R, Haubrich J, de Freitas Cassini L, et al. Stress response recruits the hippocampal endocannabinoid system for the modulation of fear memory. Learn Mem. 2010;17:202-9. https://doi.org/10.1101/lm. 1721010 .

96. Mackowiak M, Chocyk A, Dudys D, Wedzony K. Activation of CB1 cannabinoid receptors impairs memory consolidation and hippocampal polysialylated neural cell adhesion molecule expression in contextual fear conditioning. Neuroscience. 2009;158: 1708-16. https://doi.org/10.1016/j.neuroscience.2008.11.037.

97. Sachser RM, Crestani AP, Quillfeldt JA, Mello EST, de Oliveira Alvares L. The cannabinoid system in the retrosplenial cortex modulates fear memory consolidation, reconsolidation, and extinction. Learn Mem. 2015;22:584-8. https://doi.org/10.1101/lm. 039891.115.

98. Nasehi M, Davoudi K, Ebrahimi-Ghiri M, Zarrindast MR. Interplay between serotonin and cannabinoid function in the amygdala in fear conditioning. Brain Res. 2016;1636:142-51. https://doi.org/10.1016/j.brainres.2016.01.034.

99. Garcia-Gutierrez MS, Ortega-Alvaro A, Busquets-Garcia A, Perez-Ortiz JM, Caltana L, Ricatti MJ, et al. Synaptic plasticity alterations associated with memory impairment induced by deletion of CB2 cannabinoid receptors. Neuropharmacology. 2013;73:388-96. https://doi.org/10.1016/j.neuropharm.2013.05. 034.

100. Li Y, Kim J. CB2 cannabinoid receptor knockout in mice impairs contextual long-term memory and enhances spatial working memory. Neural Plast. 2016;2016:9817089. https://doi.org/10.1155/ 2016/9817089.

101. Nasehi M, Hajikhani M, Ebrahimi-Ghiri M, Zarrindast MR. Interaction between NMDA and CB2 function in the dorsal hippocampus on memory consolidation impairment: an isobologram analysis. Psychopharmacology. 2017;234:507-14. https://doi.org/ 10.1007/s00213-016-4481-9.

102. Ratano P, Everitt BJ, Milton AL. The CB1 receptor antagonist AM251 impairs reconsolidation of pavlovian fear memory in the rat basolateral amygdala. Neuropsychopharmacology. 2014;39: 2529-37. https://doi.org/10.1038/npp.2014.103.

103. Lin HC, Mao SC, Gean PW. Effects of intra-amygdala infusion of CB1 receptor agonists on the reconsolidation of fear-potentiated startle. Learn Mem. 2006;13:316-21. https://doi.org/10.1101/lm. 217006.

104. Santana F, Sierra RO, Haubrich J, Crestani AP, Duran JM, de Freitas Cassini L, et al. Involvement of the infralimbic cortex and CA1 hippocampal area in reconsolidation of a contextual fear memory through CB1 receptors: effects of CP55,940. Neurobiol Learn Mem. 2016;127:42-7. https://doi.org/10.1016/j.nlm.2015. 11.016 .

105. Suzuki A, Mukawa T, Tsukagoshi A, Frankland PW, Kida S. Activation of LVGCCs and CB1 receptors required for destabilization of reactivated contextual fear memories. Learn Mem. 2008;15:426-33. https://doi.org/10.1101/lm.888808.

106. Lee JL, Flavell CR. Inhibition and enhancement of contextual fear memory destabilization. Front Behav Neurosci. 2014;8:144. https://doi.org/10.3389/fnbeh.2014.00144.

107. Lin HC, Mao SC, Chen PS, Gean PW. Chronic cannabinoid administration in vivo compromises extinction of fear memory. Learn Mem. 2008;15:876-84. https://doi.org/10.1101/1m. 1081908.

108. ElBatsh MM, Assareh N, Marsden CA, Kendall DA. Anxiogeniclike effects of chronic cannabidiol administration in rats. Psychopharmacology. 2012;221:239-47. https://doi.org/10.1007/ s00213-011-2566-z.

109. Cheng D, Low JK, Logge W, Garner B, Karl T. Chronic cannabidiol treatment improves social and object recognition in double transgenic APPswe/PS1E9 mice. Psychopharmacology. 2014;231:3009-17. https://doi.org/10.1007/s00213-014-3478-5.

110. De Gregorio D, McLaughlin RJ, Posa L, Ochoa-Sanchez R, Enns $\mathrm{J}$, Lopez-Canul M, et al. Cannabidiol modulates serotonergic transmission and reverses both allodynia and anxiety-like behavior in a model of neuropathic pain. Pain. 2019;160:136-50. https:// doi.org/10.1097/j.pain.0000000000001386.

111. Cohen K, Weinstein A. The effects of cannabinoids on executive functions: evidence from cannabis and synthetic cannabinoids - a systematic review. Brain Sci. 2018;8:40. https://doi.org/10.3390/ brainsci8030040.

112. Szkudlarek HJ, Desai SJ, Renard J, Pereira B, Norris C, Jobson CEL, et al. Delta-9-tetrahydrocannabinol and cannabidiol produce dissociable effects on prefrontal cortical executive function and regulation of affective behaviors. Neuropsychopharmacology. 2019;44:817-25. https://doi.org/10.1038/s41386-018-0282-7.

113. Uhernik AL, Montoya ZT, Balkissoon CD, Smith JP. Learning and memory is modulated by cannabidiol when administered 
during trace fear-conditioning. Neurobiol Learn Mem. 2018;149: 68-76. https://doi.org/10.1016/j.nlm.2018.02.009.

114. Dhopeshwarkar A, Mackie K. CB2 cannabinoid receptors as a therapeutic target - what does the future hold? Mol Pharmacol. 2014;86:430-7. https://doi.org/10.1124/mol.114.094649.

115. Laricchiuta D, Centonze D, Petrosini L. Effects of endocannabinoid and endovanilloid systems on aversive memory extinction. Behav Brain Res. 2013;256:101-7. https://doi.org/10. 1016/j.bbr.2013.08.010.

116. Gobira PH, Lima IV, Batista LA, de Oliveira AC, Resstel LB, Wotjak CT, et al. N-arachidonoyl-serotonin, a dual FAAH and TRPV1 blocker, inhibits the retrieval of contextual fear memory: role of the cannabinoid CB1 receptor in the dorsal hippocampus. J Psychopharmacol. 2017;31:750-6. https://doi.org/10.1177/ 0269881117691567.

117. Dow-Edwards D, Silva L. Endocannabinoids in brain plasticity: cortical maturation, HPA axis function and behavior. Brain Res.
2017;1654(Pt B):157-64. https://doi.org/10.1016/j.brainres.2016. 08.037 .

118. Mendiguren A, Aostri E, Pineda J. Regulation of noradrenergic and serotonergic systems by cannabinoids: relevance to cannabinoid-induced effects. Life Sci. 2018;192:115-27. https:// doi.org/10.1016/j.lfs.2017.11.029.

119. Karschner EL, Darwin WD, McMahon RP, Liu F, Wright $\mathrm{S}$, Goodwin RS, et al. Subjective and physiological effects after controlled Sativex and oral THC administration. Clin Pharmacol Ther. 2011;89:400-7. https://doi.org/10.1038/ clpt.2010.318.

120. Todd SM, Arnold JC. Neural correlates of interactions between cannabidiol and Delta(9)-tetrahydrocannabinol in mice: implications for medical cannabis. Br J Pharmacol. 2016;173:53-65. https://doi.org/10.1111/bph.13333.

Publisher's Note Springer Nature remains neutral with regard to jurisdictional claims in published maps and institutional affiliations. 